\title{
FREEDOM OF EXPRESSION, COMMERCIAL EXPRESSION AND TOBACCO IN CANADA
}

\author{
Caroline Reid*
}

The application of freedom of expression protections to commercial expression is a matter of some debate. Some commentators suggest that commerciality robs expression of the value inherent in more politically, culturally, or socially motivated expression.

In Canada, the Supreme Court has found that commercial expression is entitled to protection. The affirmation of these rights subject "only to such reasonable limits prescribed by law as can be demonstrably justified in a free and democratic society" does, however, allow for the commercial nature of expression to be weighed as against the value of allowing such expression.

The Supreme Court's approach to freedom of commercial expression, as exemplified by the tobacco cases, indicates that this right is not given the same degree of protection as non-commercial expression. However, the Court's approach and refusal to introduce a specific test allows flexibility in application, and provides for the possibility that, in some cases, protections may be broad enough to place commercial expression on a par with non-commercial expression.

\section{INTRODUCTION}

Freedom of expression is fundamental to democratic societies across the world. This essay considers how the Canadian Supreme Court protects freedom of expression where expression has a commercial purpose, and whether its approach gives commercial expression sufficient protection. How the protection of freedom of expression impacts on the ability of tobacco manufacturers to advertise their products will be considered to demonstrate how commercial expression protections are put into practice.

The examination of commercial expression theory brings into focus a number of the tensions inherent in protecting free expression, which are fundamental to any examination of this right. These tensions particularly include how limitations on the right may be permitted even in societies

* Submitted as part of the LLM programme at Victoria University of Wellington. 
where free expression is protected, and how the protection can be extended to expression which may, on first inspection, not appear worthy of this protection. In addition, although this article's analysis is limited in scope to Canada, this question has wider relevance because the Canadian court has developed a unique approach to commercial expression and its protection that could be of assistance in the development of local jurisprudence.

Canada's commercial expression theory is perhaps particularly of interest to New Zealand with regard to restrictions on tobacco advertising. New Zealand's tobacco legislation, the Smoke-Free Environments Act, was described in 1991 as "one of the strongest pieces of anti-tobacco legislation ever passed". ${ }^{1}$ The tobacco advertising restrictions, unlike Canada's, have not been the subject of protracted debate in higher level courts. With new regulations requiring graphic warnings on all cigarette packages by 28 August 2008, tobacco manufacturers may consider this an opportune time to challenge New Zealand's tobacco advertising restrictions. ${ }^{2}$ Should New Zealand tobacco manufacturers decide to begin this debate, the Canadian cases concerning commercial expression and tobacco advertising may provide a useful example of how courts can balance human rights with the ability of government to restrict these rights in the best interests of citizens.

\section{BACKGROUND: CANADIAN CHARTER FRAMEWORK}

In New Zealand, section 14 of the New Zealand Bill of Rights Act protects "the freedom to seek, receive, and impart information and opinions of any kind in any form". ${ }^{3}$ This right is narrow as compared to the broad-ranging protection available in the Canadian Charter of Rights and Freedoms. This document places freedom of expression among the fundamental freedoms protected in section 2, which protects "freedom of thought, belief, opinion and expression, including freedom of the press and other media of communication". ${ }^{4}$

The constitutional protection of freedom of expression in jurisdictions across the world illustrates the centrality that freedom of expression is accorded in democratic societies. While this right is considered sufficiently fundamental to require protection in constitutional documents, however, its protection is not unlimited. In New Zealand, the rights under the New Zealand Bill of Rights Act are protected to the extent that they do not conflict with other legislation, and such "reasonable limits prescribed by law as can be justified in a free and democratic society" are

1 Robert Beaglehole "Science, Advocacy and Health Policy: Lessons from the New Zealand Tobacco Wars" (1991) 12(2) Journal of Public Health Policy 175, 175

2 Smoke-Free Environments Regulations 2007, reg 34.

3 New Zealand Bill of Rights Act 1990, s 14.

4 Constitution Act 1982, Part I: Canadian Charter of Rights and Freedoms, s 2(b). 
permitted. ${ }^{5}$ In Canada, Supreme Court case law illustrates a framework within which the constitutionality of limits being placed on Charter rights may be considered.

\section{A Justified Limits and R v Oakes}

The Canadian Supreme Court has the power to strike out legislation considered inconsistent with the Charter of Rights and Freedoms, unlike New Zealand courts that find inconsistency with the Bill of Rights Act. This ability is subject to section 1 of the Charter, which affirms rights subject "only to such reasonable limits prescribed by law as can be demonstrably justified in a free and democratic society". ${ }^{6} R v$ Oakes (Oakes) provides a test through which section 1 can be considered in regard to all Charter protected rights. ${ }^{7}$

The Oakes test has two components for testing whether a legislative limit on a right is reasonable and demonstrably justified. The first is that the objective the limit is designed to achieve must be sufficiently important to warrant overriding a protected right. At a minimum, the objective must "relate to concerns which are pressing and substantial in a free and democratic society". 8

The second limb of the test is that the party limiting the right must show that the means chosen to achieve the objective are themselves reasonable and demonstrably justified, through some form of proportionality test. ${ }^{9}$ In Oakes, this test involved three considerations: (1) whether the measures are designed to achieve the objective (that is, whether they are rationally connected); (2) whether the limits placed on the rights impair them as little as possible; and (3) whether the effect of the impairment is proportional to the importance of the objective identified as the reason for putting it in place. ${ }^{10}$

This test allows the Supreme Court to consider cases using a broad view. The Court's current approach is to construe rights widely, but allow strict limitations. This has been referred to as a "mismatch", with rights given wide definition but a far "less solicitous" approach used to determine whether limitations on rights may be justified. ${ }^{11}$ In actuality, the approach is not contradictory, but designed to recognise that rights as fundamental as those protected in the Charter require wide scope, even though they must sometimes be limited to protect wider societal interests.

5 New Zealand Bill of Rights Act 1990, ss 4-5.

6 Constitution Act 1982, Part I: Canadian Charter of Rights and Freedoms, s 1.

$7 \quad R v$ Oakes [1986] 1 SCR 103.

8 Ibid, para 69 Dickson CJ for the Court.

9 Ibid, para 70 Dickson CJ for the Court.

10 Ibid.

11 Refers to Richard Moon's analysis in Denise Meyerson "The Legitimate Extent of Freedom of Expression" (2002) 52 U Toronto LJ 331, 333-334. 
Under Oakes, it could theoretically be easier in cases of commercial expression to argue that the limits placed on expression are demonstrably justified. Although the wide definition used in freedom of expression cases ensures that commercial expression is entitled to protection, the perceived lack of value of expression considered to be purely economic will affect considerations of the justifiability of limitations.

\section{B Edmonton Journal and the Contextual Approach}

It is not only by the application of section 1 that commercial expression may be granted lesser protection than non-commercial expression. In Edmonton Journal v Alberta (Edmonton Journal), Wilson $\mathrm{J}$ outlined two different approaches used by Canadian courts in regard to the Charter's application. The first of these approaches, the "abstract" approach, considers a right in isolation, taking into account the importance of the right and the seriousness of any decision to restrict it. ${ }^{12}$ The second approach, preferred by Wilson J, was what she referred to as the "contextual" approach. This approach balances competing rights rather than "assess[ing] the relative importance of the competing values in the abstract". ${ }^{13}$ The contextual approach allows courts to recognise that "a particular right or freedom may have a different value depending on the context". ${ }^{14}$

This contextual approach gives courts greater leeway to consider freedom of expression on a case-by-case basis, taking into account individual circumstances - like, for example, the commercial nature of expression. This approach was followed in Rocket $v$ Royal College of Dental Surgeons (Rocket), which will be referred to in greater detail when commercial expression is discussed later in this article. ${ }^{15}$

\section{Conclusion: Protecting Rights in Canada}

Oakes and Edmonton Journal, in tandem, present a clear direction for rights protection by the Canadian Supreme Court. The Court has shown, through adherence to these cases, that the Charter protection of rights and freedoms does not require the Court to follow a procedure that recognises only the abstract value of protected rights. Oakes and Edmonton Journal instead both promote the understanding that, while rights and their protection do have intrinsic value, in individual cases there may be merit in their limitation and as such a case-by-case approach is best. A limitation may be justified either because the limitation is for a compelling and socially efficacious reason or both because the limitation is for a compelling and socially efficacious reason and because in the individual circumstances the right is less compelling, so less reason is needed to limit it.

12 Edmonton Journal v Alberta (Attorney General) [1989] 2 SCR 1326, 1352-1353 Wilson J.

13 Ibid, 1353 Wilson J.

14 Ibid, 1355 Wilson J.

15 Rocket v Royal College of Dental Surgeons (Ontario) [1990] 2 SCR 232. 


\section{FREEDOM OF EXPRESSION}

The framework in place for protecting rights and freedoms through the Canadian Charter exists because these rights and freedoms are considered to be of such value as to merit constitutional protection. Freedom of expression, specifically, is considered intrinsic to democratic society. While its protection in Canada is currently most recognisable by its incorporation into the Charter of Rights and Freedoms, the right "is not ... a creature of the Charter". ${ }^{16}$ Estey J referred to freedom of expression as "a fundamental right", with a history that can be traced to the Bill of Rights of $1689 .{ }^{17}$ The fundamental nature of this right is rooted in the recognition that democratic institutions "derive their efficacy from the free public discussion of affairs". ${ }^{18}$

The protection of freedom of expression across the world is premised on a similar set of reasons. In 1963, Thomas Emerson stated that free expression was necessary to assure individual selffulfilment, to attain truth, to enable participation in social and political decision-making, and to maintain "the balance between stability and change in the society". ${ }^{19}$ The purpose of a free expression system is, according to Emerson, "to allow individuals to realize their potentialities and to facilitate social change through reason and agreement rather than force and violence". ${ }^{20}$

Emerson's four grounds for protecting freedom of expression can be distilled into three categories. Robert Sharpe identified the three main theories of American scholars, who state that the constitutional protection of freedom of expression: ${ }^{21}$

(1) is "essential to intelligent and democratic self-government";

(2) enhances "the search for truth" by protecting open exchange and "creating a competitive market-place of ideas"; and

(3) is "essential to personal growth and self-realization".

\section{A Democratic Self-Government}

The first of these theories, that freedom of expression is necessary for the operation of democratic societies, has already been referred to in passing. In Irwin Toy Ltd v Quebec (Irwin Toy), this theory is incorporated in the majority's consideration that "participation in social and political

16 Dolphin Delivery Ltd v RWDSU, Local 580 [1986] 2 SCR 573 para 12, McIntyre J.

17 Attorney General of Canada v Law Society of British Colombia [1982] 2 SCR 307, 362 Estey J for the Court (the Jabour case).

18 Re Alberta Statutes [1938] SCR 100, 133 Duff CJ.

19 Thomas I Emerson "Toward a General Theory of the First Amendment" (1963) 72 Yale LJ 877, 878-879.

20 Thomas I Emerson "Freedom of Association and Freedom of Expression" (1964) 74 Yale LJ 1, 22.

21 Robert J Sharpe "Commercial Expression and the Charter" (1987) 37 U Toronto LJ 229, 232. 
decision-making is to be fostered and encouraged". ${ }^{22}$ According to Keith Dubick, four main democratic goals are forwarded by permitting free expression: the promotion of self-government by an informed citizenry, the preservation of social stability, accountability of officials, and increased confidence in the political system. ${ }^{23}$ As Emerson stated in 1963, "the crucial point ... is not that freedom of expression is politically useful, but that it is indispensable to the operation of a democratic form of government". ${ }^{24}$ Freedom of expression enables citizens to be informed and inform others, to debate the value of ideas and opinions, to recognise and discuss the operation and effect of democratic government, and, in the end, to recognise and confirm the legitimacy of that system in a manner that promotes its stability.

\section{B The Market-Place of Ideas and Pursuit of Truth}

The second main theory protecting freedom of expression rests upon the understanding that truth is a good in and of itself. According to the Supreme Court in Irwin Toy, "seeking and attaining the truth is an inherently good activity". ${ }^{25}$ Whether all expression can be considered relevant to a search for truth is another consideration entirely, but it is likely that attempting to determine what expression has value in such a search allows too much power to legislators and the judiciary to define what opinions may or may not legitimately be challenged.

In this regard, hate speech might be a relevant example. Much like commercial expression, courts and academics have grappled with how expression disseminating hatred for groups can be treated in the context of free expression theory. According to Stefan Braun, the censorship of hate speech, while intended to correct "wrongful social hegemony" forgets that "the essence of hegemony is denial of independent cognitive choice". ${ }^{26}$ As such, censorship of hate speech "perverts" public expression protections by "officially ensuring a correct social agenda". ${ }^{27}$ Nevertheless, the courts, including the Canadian Supreme Court, have permitted the censorship of hate propaganda. In $R v$ Keegstra, the Canadian Supreme Court found that by suppressing this form

22 Irwin Toy Ltd v Quebec (Attorney General) [1989] 1 SCR 927 para 54, Dickson CJ and Lamer and Wilson JJ [Irwin Toy].

23 Keith Dubick "The Theoretical Foundation for Protecting Freedom of Expression" (2001) 13 Nat'l J Const L 1, 15.

24 Emerson "Toward a General Theory of the First Amendment", above n 19, 883.

25 Irwin Toy, above n 23, para 54 Dickson CJ and Lamer and Wilson JJ.

26 Stefan Braun Democracy Off Balance: Freedom of Expression and Hate Propaganda Law in Canada (University of Toronto Press, Toronto, 2004) 19.

27 Ibid. 
of expression, freedom of expression is actually forwarded because the aim of hate propaganda is to silence or exclude particular groups from society and the democratic process. ${ }^{28}$

Concern about censorship must remain. For by permitting courts and the legislature to determine what opinions may legally be expressed, state officials become by default "arbiters of truth", a role for which many may possess neither the knowledge nor competence required for performance. ${ }^{29}$ The remedy for expression considered to be harmful may instead be more expression. Brandeis J, in Whitney $v$ California, introduced a doctrine now termed "counterspeech", in which he stated that "the remedy to be applied is more speech, not enforced silence", provided that there is time to "expose through discussion the falsehood and fallacies, to avert the evil by the processes of education". ${ }^{30}$ While there is inequity in the ability of individuals and organisations to disseminate opinions to the public, it may well be that counterspeech should still "be the remedy of first resort". 31

Counterspeech proponents and opposition to censorship illustrate how free expression theory is grounded upon the understanding that a greater diversity of views will better enable truth to emerge. The perception that truth may be discovered though opposition can be traced back to John Milton, whose comment "Let [Truth] and Falsehood grapple; who ever knew Truth put to the worse in a free and open encounter?" still rings true for free expression theorists. ${ }^{32}$ John Stuart Mill developed the pursuit of truth and market-place of ideas theory in On Liberty. His theory is based on the understanding that there is only benefit in allowing a range of ideas and opinions - including those considered to be morally or factually wrong or indefensible such as hate propaganda - into the public arena. Mill objected to censorship on the grounds that it deprives those holding a wrong opinion of the "opportunity of exchanging error for truth", and that it also deprives those holding a correct opinion of "the clearer perception and livelier impression of truth produced by its collision with error". ${ }^{33}$ According to Mill, truth is more valuable if it is known rather than received, understood rather than taught. Mill's pursuit of truth theory places at the forefront the development of citizens and their improvement, and that of society, through information and debate.

$28 R$ V Keegstra [1990] 3 SCR 697, as outlined in Terry Heinrichs "Censorship as Free Speech! Free Expression Values and the Logic of Silencing in $R v$ Keegstra" (1998) 36 Alberta L Rev 835.

29 Heinrichs, ibid, 849.

30 Whitney v California (1927) 274 US 357, 377 Brandeis J, as quoted in Robert D Richards and Clay Calvert "Counterspeech 2000: A New Look at the Old Remedy for 'Bad' Speech" (2000) BYUL Rev 553, 554.

31 Richards and Calvert, ibid, 586.

32 John Milton, as quoted in Joseph J Hemmer, Jr The First Amendment: Theoretical Perspectives (Hampton Press, Inc, Cresskill, New Jersey, 2006) 7.

33 John Stuart Mill On Liberty (Penguin Books, London, 1974) 76. 


\section{Personal Autonomy and Self-Realisation}

Sharpe's third theory rests on the understanding that personal autonomy and self-fulfilment can only flourish within a society that supports the rights of individuals to form and express their opinions free of censorship. Being able to form and communicate opinions and beliefs is "an indispensable part of the human experience". ${ }^{34}$ Again, just as not all expression will contribute to a search for truth, nor will all expression contribute to self-realisation. However, as this ground for free expression protection is rooted in the individual it cannot be possible to determine what expression will, and what will not, promote such self-development.

Emerson comments that this theory derives "from the widely accepted premise of Western thought that the proper end of man is the realization of his character and potentialities as a human being". ${ }^{35}$ If, as Emerson continues, "expression is an integral part of the development of ideas, of mental exploration and of the affirmation of self", then the suppression of expression must necessarily stunt individual self-development and the realisation of individual potential. ${ }^{36}$

According to Irwin Toy: ${ }^{37}$

the diversity in forms of individual self-fulfillment and human flourishing ought to be cultivated in an essentially tolerant, indeed welcoming, environment not only for the sake of those who convey a meaning, but also for the sake of those for whom it is conveyed.

While this quotation refers specifically to the self-fulfilment aspect of freedom of expression theory, it highlights a wider issue that will be considered in greater detail when freedom of expression theories are applied to commercial expression. That issue is that the rights protected do not always, or even mostly, belong to the speaker of expression, although the right is framed as a right to express rather than as a right to hear expression. The right to free expression "would be of little value either to the public or to the individual if this right did not include the right to be heard". ${ }^{38}$ The right of some members of the public to express their opinions enables other members of the public to be aware of differing views and develop their own informed opinions. Thus, the market-place of ideas and pursuit for truth can enable individuals to make decisions and hold beliefs that will promote their autonomy and self-fulfilment even when they are not party to the original expression.

34 Dubick, above n 23, 40.

Emerson "Toward a General Theory of the First Amendment", above n 20, 879.

Ibid.

Irwin Toy, above n 22, para 54 Dickson CJ and Lamer and Wilson JJ.

38 Carys J Craig "Putting the Community in Communication: Dissolving the Conflict Between Freedom of Expression and Copyright" (2006) 56 U Toronto LJ 75, 103. 


\section{FREEDOM OF COMMERCIAL EXPRESSION}

Freedom of expression, broadly defined, can be invoked to support a wide and varied scope of activity that stretches well beyond political purposes. One example of the difficulties inherent in this broad meaning is the debate that exists as to whether protecting freedom of expression in a commercial context necessarily promotes the same values as protecting non-commercial expression. According to Roger Shiner, the "appropriation" of constitutional protections for commercial expression is a "conceptual and normative fraud", defacing the ideal of "human beings as autonomous choosers, and of human flourishing as relying on freely chosen sociality" upon which Shiner claims the freedom rests. ${ }^{39}$ This view illustrates the concern of commentators about applying freedom of expression protections in commercial contexts without consideration of what the values being protected by the freedom actually comprise.

Two main reasons are used by the courts to justify the inclusion of commercial expression within the protection of freedom of expression. The first is that the definition of "expression" used by the courts includes commercial expression, and that such speech contributes to the "marketplace of ideas". ${ }^{40}$ The second is "the difficulty in distinguishing commercial expression from other kinds of expression". ${ }^{41}$ Even pure commercial expression, the goal of which is to sell goods and services, may contain material that has political, social, or moral value.

These cannot be seen as the sole reasons why freedom of expression protections have been extended to commercial expression, however. They do not address the issue of whether commercial expression, in itself, has sufficient merit to warrant constitutional protection.

\section{A The Theoretical Approach}

Many commentators have suggested that the reasons for protecting commercial expression are the same as those used to support wider free expression. By using Robert Sharpe's framework for freedom of expression it is clear that commercial speech has value that entitles it to protection on its own merit. Sharpe acknowledges that protecting freedom of commercial expression does not directly contribute to democratic government, but argues that the other two bulwarks of free expression - the protection of open exchange and a market-place of ideas in order to enable the search for truth, and the ability of free expression to contribute to personal self-realisation - can be seen to apply directly to commercial expression.

Martin Redish has theorised that individual self-realisation is the central value served by the protection of free expression. According to Redish, other values are "in reality subvalues of self-

39 Roger Shiner Freedom of Commercial Expression (Oxford University Press, Oxford, 2003) 3.

40 Elizabeth L McNaughton and Christopher M Goodridge "The Canadian Approach to Freedom of Expression and the Regulation of Food and Drug Advertising" (2003) 58 Food Drug LJ 521, 524.

41 Ibid. 
realization". ${ }^{42}$ While this may be overstating the point with regard to general free expression theory, which this article will not discuss in more depth, it is clear that with regard to commercial expression, there is some value in this interpretation. Through permitting information to be disseminated to contribute to a market-place of ideas that has as its goal a search for truth, commercial expression protection enables individual economic autonomy and self-realisation for the consumer. Although Sharpe acknowledges that manipulative or misleading advertising should not be permitted, he comments that "[t]he self-development and individual growth of the listener may be facilitated by" information received through advertising. ${ }^{43}$ Thus the protection of commercial expression can be seen to be supported by the market-place of ideas and pursuit of truth aspect of free expression theory, but primarily exists because the market-place of ideas enables information to be of value to individuals in their interaction with the world and with commercial decision-making.

This highlights the importance, in cases of commercial expression, of the rights of the listener or consumer, and the importance of the benefit they derive from a free market-place of ideas. For the protection of commercial expression is premised far more on the right to be informed than the right to inform. As Sharpe comments, it is rare that advertising can "embody the individual goals, values, or objectives of the speaker", reflecting, as it does instead, a corporate and consumer-driven profit motive. ${ }^{44}$ This "profit motive" is an important reason given by the courts to justify their consideration that commercial expression is less valuable than non-commercial expression, but it is insufficient to deprive commercial expression of all value. According to Martin Redish, the fact that the motivation for advertising is to increase the profits of the advertiser "in no way" distinguishes a message itself from "the overwhelming majority of fully protected contributions to public debate", which may also be motivated by some private aim of the speaker. ${ }^{45}$

In theory, the right to free expression is framed as a right belonging to the speaker: a right to speak and share opinions. The necessary corollary of this right is of course that permitting such speech enables the public to be aware of and informed about dissent and opinions that both do and do not support the status quo, and use this knowledge in the framing of their own opinions. Richard Moon has developed a theory about freedom of expression protecting not individual freedoms or liberties, but instead "the individual from state interference with his or her liberty or freedom to communicate with others". ${ }^{46}$ Moon's communication theory emphasises the importance of

42 Martin Redish Freedom of Expression: A Critical Analysis (Michie Company, Charlottesville, Virginia, 1984) 9-13, as quoted in Hemmer, above n 32, 117.

43 Sharpe, above n 21, 237.

44 Ibid, 236

45 Martin H Redish "First Amendment Theory and the Demise of the Commercial Speech Distinction: the Case of the Smoking Controversy" (1997) 24 N Ky L Rev 553, 581-582.

46 Richard Moon "Justified Limits on Free Expression: The Collapse of the General Approach to Limits on Charter Rights" (2002) 40 Osgoode Hall LJ 337, 341. 
interaction between individuals, and his understanding is that expression is important because "our understanding of self and the world develops through communication with others". ${ }^{47}$ Thus the protection of freedom of expression protects both the public as a whole and individuals by "protecting a social practice - a relationship of communication" which, in the case of commercial expression, enables consumers to be informed so that they can make knowledgeable economic choices. ${ }^{48}$ It is this flow-on effect of permitting free speech that lends most support to the idea that commercial expression requires protection too.

Sharpe's position, and that of other proponents of commercial expression protection such as Redish and Moon, is not without its opponents. Chief among these is Roger Shiner, whose Freedom of Commercial Expression makes a very strong argument against extending the protection to commercial expression. According to Shiner, freedom of expression can be seen as "a basic manifestation of personal autonomy, or a fundamental precondition for the exercise of such autonomy". 49 Because the value of personal autonomy is a value "for natural persons", Shiner argues that "it makes little sense to see them as values for corporations" 50 - a position that reflects Sharpe's comment that it is difficult to see the rights of corporations being infringed by limitations on commercial expression. Michael Mandel has phrased this argument in a slightly different way, claiming that commercial expression is itself an "expression of economic power", the right to exercise it being "restricted to people with property", and as such protecting it as a right is a protection of privilege. ${ }^{51}$ Nevertheless it seems an argument without justification to state that simply because corporations are not individuals, and that they are not powerless, that they are not entitled to some of the protections, if not the same degree of protection, as other legal persons.

Shiner's approach to free expression positions it as a right belonging to individuals - the speaker of expression and seeker of truth - rather than to society as a whole. Shiner does not effectively respond to the argument that the value of commercial expression lies largely in the information that is able to be conveyed to consumers, rather than in the freedom to express belonging to the speaker. Instead, Shiner states that "informed economic choice", seen by a number of other academics and the courts to enable freedom and personal autonomy, "is not necessary for self-fulfilment and autonomy" as "there are many other ways of life that fulfil the self and are autonomous, such that in them informed economic choice plays little or no part". ${ }^{52}$ This misses the point that dependency on

47 Ibid.

48 Richard Moon "Symposium: 20 Years Under the Charter: Shorter Commentaries: Freedom of Expression and the Canadian Charter of Rights" (2002) 21 Windsor YB Access Just 563, 563.

49 Shiner, above n 39, 125.

50 Ibid, 189.

51 Michael Mandel The Charter of Rights and the Legalization of Politics in Canada (2 ed, Thompson Educational Publishing, Inc, Toronto, 1994) 331.

52 Shiner, above n 39, 228. 
the commercial information provided through advertising may limit the informed decisions able to be made by individuals in a society where economic decisions may often be crucial ones.

Shiner's interpretation of free expression theory seems limited. As long as the value of commercial expression rests principally on the ability of consumers to exercise their right to autonomous choice through availing themselves of information that benefits their life and individual self-realisation, Shiner cannot realistically claim that because the protection is aimed at individuals it cannot protect corporations. For what does allowing commercial expression to inform consumers and enable them to make the best and most appropriate choices do but protect individuals and advance individual rights? Shiner may not be comfortable with allowing free expression protection to extend to corporations, but by denying this protection he also denies protection to those individuals whose information depends upon commercial communications. Shiner's understanding of free expression resting upon the ideal of "human beings as autonomous choosers" in actuality must support the argument in favour of the protection of commercial expression, for without a diversity of views from which to choose, human beings cannot be truly autonomous. ${ }^{53}$

\section{B The Case Law}

As previously stated, the Supreme Court's main justifications for protecting commercial expression are that the definition of expression is broad enough to incorporate commercial expression within its ambit, and that there is value in the truth, even where a commercial truth is the object.

The Supreme Court of Canada considered whether commercial expression was entitled to protection under the Charter of Rights and Freedoms in Ford $v$ Quebec (Ford). ${ }^{54}$ The unanimous judgment concluded that "no sound basis" existed upon which commercial expression should be excluded from the protection. ${ }^{55}$ The Court affirmed that commercial expression "plays a significant role in enabling individuals to make informed economic choices, an important aspect of individual self-fulfillment and personal autonomy". ${ }^{56}$ This approach was confirmed in Irwin Toy, where the majority stated that "[a]ctivity is expressive if it attempts to convey a meaning", and that the protection in the Charter applies to all expression, "however unpopular, distasteful or contrary to the mainstream", ${ }^{57}$ a definition so broad as to include hate speech and make the exclusion of commercial expression impossible without considerable effort. These cases thus draw upon the theoretical constructs of a free market-place of ideas and personal autonomy and choice.

53 Ibid, 3.

54 Ford v Quebec (Attorney General) [1988] 2 SCR 712.

55 Ibid, para 59 Judgment of the Court.

56 Ibid.

57 Irwin Toy, above n 22, para 42 Dickson CJ, Lamer and Wilson JJ. 
In Ford and Irwin Toy, the Canadian Supreme Court found that the Charter right to freedom of expression was applicable to commercial expression. This does not necessarily entitle commercial expression to the same degree of protection in practice as non-commercial expression. In Rocket the Supreme Court recognised that the commercial nature of expression is relevant to the consideration of whether breaches are justified. ${ }^{58}$ Moreover, in Rocket the Court deliberately refrained from following United States precedent for dealing with commercial expression. In the United States, specifically directed and limited protection is afforded to commercial expression, amounting to its having a "subordinate First Amendment position".59 The approach of American courts to determining whether limits on expression are justified is through a four-stage test described in Central Hudson Gas \& Electric (Central Hudson). ${ }^{60}$ This test considers: (1) whether the expression in question was false or misleading; (2) whether any regulation furthers a substantial government interest; (3) whether the interest is directly advanced by the regulation; and (4) whether any more limited restriction could have equally advanced the interest. ${ }^{61}$ Martin Redish has criticised the American test as not appearing to allow the courts to consider "the nature of the regulation's specific impact on First Amendment concerns". 62

In Rocket, instead of a specific, commercial expression, test, Oakes was used. However, as Peter Hogg has commented, the test in Oakes "bears striking similarities" to the commercial expression test that had been set in the United States by Central Hudson six years prior to Oakes. ${ }^{63}$ The major difference between the Canadian approach and the American may not be that different factors are considered, but that in Canada the test followed is non-specific, applying to all Charter rights rather than being designed to address commercial expression and symbolise its lesser value. As the Court stated in Rocket, section 1 of the Charter permitted "a sensitive, case-oriented approach" to restricting expression, including commercial expression. ${ }^{64}$ Rocket is often used to illustrate the principle that "analysis of the context of the infringing rule is fundamental to applying" the test laid out in section 1 of the Charter, following on from and confirming Edmonton Journal's contextual approach. ${ }^{65}$ By the time Rocket was heard, section 1, and the Oakes test's application of the section,

58 Rocket v Royal College of Dental Surgeons (Ontario), above n 16 McLachlin J for the Court.

59 Howard K Jeruchimowitz "Tobacco Advertisements and Commercial Speech Balancing: A Potential Cancer to Truthful, Nonmisleading Advertisements of Lawful Products" (1997) 82 Cornell L Rev 432, 443.

60 Central Hudson Gas \& Electric Corporation v Public Service Commission of New York (1980) 447 US 557.

61 Ibid, 566 Powell $\mathrm{J}$ for the Court.

62 Redish, above n 45, 559.

63 See Andrew Petter "Taking Dialogue Theory Much Too Seriously (Or Perhaps Charter Dialogue Isn't Such a Good Thing After All)" (2007) 45 Osgoode Hall LJ 147, 158.

64 Rocket $v$ Royal College of Dental Surgeons (Ontario), above n 15, 246.

65 Catherine Beagan Flood "Freedom of Commercial Expression: The Most Undervalued Charter Right" (2006) 21 Nat'l J Const L 271, 284. 
already enabled cases of commercial expression to be considered on their individual merits, without requiring a further, more specific test that deliberately assigned lesser importance to commercial expression.

\section{Summary of the Supreme Court's Approach to Commercial Expression}

The Canadian Supreme Court has recognised, and continues to recognise, the value of protecting free expression, including in situations where expression occurs within the commercial sphere. The Court justifies this protection on the basis that commercial expression "has intrinsic value as expression in its own right, it protects listeners and speakers, and it plays a significant role in the making of economic choices, which is important for self-realization". ${ }^{66}$ Because there are fewer reasons to protect commercial expression as opposed to non-commercial expression, the Court will approach cases differently, and require a lower threshold to permit limitations on commercial expression.

The Canadian Supreme Court's decision not to pursue the American approach of a specific test for the permissibility of limitations upon commercial speech indicates a preference on the Court's part not to differentiate between types of expression. Oakes and Edmonton Journal allow the Court sufficient flexibility to be able to apply different values to commercial expression cases without requiring a specific test. By relying on this approach, the Court has reserved the ability to determine each freedom of expression case on its own individual merits, rather than being tied to an approach that subordinates the rights and freedoms inherent in expression because of that expression's source and nature.

\section{CASE STUDY: TOBACCO}

Commercial expression protection, like all other freedom of expression protection, is subject to limitations. How these limitations operate in practice sheds further light upon courts' perception of the value of commercial speech and the importance of a case-by-case approach. Tobacco is a useful case study to show how application of the Supreme Court's commercial expression theory can permit relatively stringent restrictions on expression. In particular, the tobacco example illustrates how opposition to a particular point of view may be eradicated if, in addition to being unpopular, this opposition is considered to bear some kind of moral or ethical stigma. It is difficult to consider a situation, other than hate speech, in which an entire body of non-commercial expression would be permitted to be stifled in order to protect public morality or ensure that a particular view was not publicised.

66 Karla K Gower "Looking Northward: Canada's Approach to Commercial Expression" (2005) 10 Com L \& Pol'y 29, 58. 
The tobacco cases illustrate the fact that greater restriction may be permitted in regard to commercial expression, provided that the legislature has a clear and rationally connected reason for limiting expression.

\section{A Tobacco, its History, Spread, and Effects}

Tobacco has been a part of western culture since its discovery by Columbus in 1492. Historian Charles E Hatch commented in 1942 that "[t]he almost universal acceptance of the plant can be seen on every hand today", ${ }^{67}$ and while this may no longer be the case, the spread of tobacco use across the world was rapid and all-encompassing. By 1600, smoking had become prevalent in London and throughout English and Irish cities. ${ }^{68}$ By the end of the seventeenth century, tobacco use had spread "throughout the diverse strata of Indian society". ${ }^{9}$

Even as tobacco use increased and tobacco entrenched itself in mainstream culture, opposition has multiplied, protesting tobacco's growth, manufacture, use, and effects. In the early seventeenth century, King James I in England and Jahangir, the ruler of the Mughal empire, opposed tobacco use. King James' Counterblaste, published in a collection of works in 1616, referred to tobacco use as: ${ }^{70}$

A custome loathesome to the eye, hateful to the nose, harmfull to the braine, dangerous to the lungs, and in the blacke stinking fume thereof neerest resembling the horrible Stigian smoake of the pit that is bottomlesse.

Meanwhile, Jahangir issued a "more well-intentioned than successful" decree forbidding the smoking of tobacco in $1617{ }^{.71}$

Tobacco use continued to increase up to the twentieth century, with publicity from its use by the rich and famous, clever marketing campaigns, and an association of "coolness" assisting its spread. After World War II, half of all Americans smoked. ${ }^{72}$ This began to change in the 1950s, when

67 Charles E Hatch, Jr "Tobacco: Its History Illustrated by the Books, Manuscripts and Engravings in the Library of George Arents, Jr, by Jerome E Brooks" (1942) 2nd Ser 22(2) William and Mary College Quarterly Historical Magazine 101, 103.

68 Ibid, 107.

69 B G Gokhale "Tobacco in Seventeenth-Century India" (1974) 48(4) Agricultural History 484, 491.

70 See John Crawford "On the History and Consumption of Tobacco" (1853) 16(1) Journal of the Statistical Society of London 45, 47-48.

71 Gokhale, above n 69, 484.

72 Carrick Mollenkamp and others The People vs Big Tobacco: How the States Took On the Cigarette Giants (Bloomberg Press, Princeton, 1998) 18. 
serious scientific research began to suggest links between smoking and a number of debilitating, and in some cases fatal, diseases. ${ }^{73}$

\section{B Canada, Freedom of Expression, and Tobacco}

Despite a new understanding of the dangers of tobacco, people continue to smoke. In the United States alone the tobacco industry generated $\$ 200$ billion a year in the late 1990s, the equivalent of an economy the size of Turkey or Austria. ${ }^{74}$ These figures are not welcomed by those concerned about public health. In Canada, where the total retail value of tobacco sales in 1992 was only \$9.8 billion, ${ }^{75}$ the deaths of approximately 45,000 people annually are considered to be the result of tobacco-related illnesses. ${ }^{76}$ The World Health Organisation has estimated that nearly six million people will die of tobacco-related illnesses in developing countries by $2020 .{ }^{77}$

For this reason, governments around the world consider that it is important to reduce tobacco use among their citizens, and support this aim by implementing legislation. According to the World Health Organisation, legislation "is one of the strongest weapons to combat the world smoking epidemic". ${ }^{78}$ Central to legislative attempts to reduce smoking are restrictions on advertising, promotion, and sponsorship of sporting and cultural activities by tobacco manufacturers.

Legislative attempts to curb tobacco use have occurred in numerous countries, including New Zealand, the United Kingdom, the United States, Australia, and Canada. In 1995, the Supreme Court of Canada considered the case of RJR-MacDonald Inc $v$ Canada (RJR-MacDonald), in which Canadian tobacco manufacturers banded together to protest the effect of the Tobacco Products Control Act. ${ }^{79}$ This Act prohibited "virtually all direct and indirect advertising of tobacco products in Canada". ${ }^{80}$ The majority determined that the prohibition on advertising was unconstitutional, as it infringed upon the right of freedom of expression available through the Charter. In June 2007, the Canadian Supreme Court had a chance to revisit this decision in JTI MacDonald Corp v Canada (JTI MacDonald).

73 Ibid, 17.

74 Ibid, 15.

75 Rob Cunningham "RJR-MacDonald Inc v Canada (AG): Reflections from the Perspective of Health" (1995) 40 McGill LJ 229, 236.

76 JTI Macdonald Corp v Canada (Attorney General) [2007] SCC 30, para 13 McLachlin CJ for the Court.

77 Melissa E Crow "Smokescreens and State Responsibility: Using Human Rights Strategies to Promote Global Tobacco Control" (2004) 29 Yale J Int'l L 209-211.

78 World Health Organization Legislative Responses to Tobacco Use (Martinus Nijhoff Publishers, Dordrecht, 1991) ix.

79 RJR-MacDonald Inc v Canada (Attorney General) [1995] 3 SCR 199.

80 Cunningham, above n 75, 229. 
A factor considered in cases involving tobacco advertising restrictions is the extent to which restricting advertising limits the rights of consumers. How much is the right to freedom of expression a right belonging to the speaker, and how much a right belonging to the listener - or, in this case, consumer? As discussed in earlier in this paper, the line is not easy to draw on this point, particularly with regard to commercial expression. Freedom of expression, after all, protects not only the right to express one's ideas, but the ability to hear others express theirs.

\section{RJR-MacDonald}

Considered by Roger Shiner to be "a cautionary tale for the Supreme Court of Canada's approach to freedom of commercial expression", ${ }^{81}$ RJR-MacDonald considered the constitutionality of an almost complete ban on tobacco advertising. The majority in this case held that the value of freedom of expression was such, and the case put forward by the State so lacking in justification, that the portions of the legislation restricting this freedom were inconsistent with the Charter and of no effect.

La Forest $\mathrm{J}$ in this case delivered a detailed dissenting judgment that delved into the debates presented during the passage of the Act through the Canadian House of Commons. This debate clarified what the legislature considered the purpose of the Act to be. According to Jake Epp, then Minister of National Health and Welfare, his "primary concern" in discouraging tobacco advertising and promotion was "the health of Canadians". ${ }^{82}$ All judgments agree that this concern is valid, and one of sufficient value to meet the first stage of the Oakes test, being a concern that is at least "pressing and substantial" in a free and democratic society. ${ }^{83}$

It was by application of the second stage of the Oakes test - the proportionality test - that the majority held that the Act was an unjustifiable limit on freedom of expression. The limitations failed at the first branch of this stage, whether the measures were rationally connected to the desired objective, as the legislature did not prove that advertising restrictions would advance the objective stated. Iacobucci $\mathrm{J}$ acknowledged that there may have been a justifiable basis for the limitation on the right, but "in my view the record does not establish it". ${ }^{84}$ Indeed, La Forest J has been criticised for finding a causal connection between tobacco advertising and the use of tobacco products in this case. ${ }^{85}$ Without a proven link it would have been impossible for the Court to find a rational connection between the limits on advertising and the objective of protecting the health of Canadians.

81 Shiner, above n 39, 85.

82 See RJR-MacDonald Inc v Canada, above n 80, para 30 La Forest J dissenting.

$83 R v$ Oakes, above n 7, para 69 Dickson CJ for the Court.

84 RJR-MacDonald Inc v Canada, above n 79, para 191 Iacobucci J.

85 Arnie Herschorn "Causation of Harm and the Charter Guarantee of Freedom of Expression" (2003) 14 Nat'l J Const L 217, 231. 
In cases where legislation limiting rights is intended to "change human behaviour", when it is "impossible to demonstrate a causal connection" between the limitation and the harm it is designed to address, the Canadian Supreme Court may be willing to accept evidence that is "convincing to a reasonable person" where no scientific evidence is available. ${ }^{86}$ In RJR-MacDonald, the legislature failed to provide even sufficient evidence to meet this lower burden. As McLachlin J stated: ${ }^{87}$

Freedom of expression, even commercial expression, is an important and fundamental tenet of a free and democratic society. If Parliament wishes to infringe this freedom, it must be prepared to offer good and sufficient justification for the infringement and its ambit. This it has not done.

The failure of the government in this case to justify the restrictions on tobacco advertising resulted in the court upholding tobacco manufacturers' claims, striking out portions of the Tobacco Products Control Act as contrary to the Charter. A number of judges, both in the majority and in dissent, commented that it was difficult to see how, when "Parliament has chosen not to criminalize tobacco use", the advertising of tobacco products "can somehow take on the character of criminal activity". ${ }^{88}$

\section{JTI MacDonald}

Twelve years after the decision reached in RJR-MacDonald, the Supreme Court of Canada upheld the constitutionality of limits on tobacco advertising. ${ }^{89}$ Considering a different legislative framework of restriction, a unanimous judgment delivered by McLachlin CJ determined that restrictions placed upon tobacco advertising, while infringing the right of freedom of expression, met the justification standards of section 1 of the Charter and fit within the Oakes test.

The new Act did not have a blanket ban in the same way as its predecessor. Instead, it permitted informational and brand preference advertising, while forbidding lifestyle advertising; promotion; false or misleading advertisements; or those aimed at young persons, and increasing the size of the mandatory warning labels on packages from 33 to 50 per cent of the total display. ${ }^{90}$ Section 4 of the Act also provided a detailed purpose statement that allowed the Court to more easily identify a rational connection between this and the limits set out in the Act. This section stated that the Act provided "a legislative response to a national public health problem of substantial and pressing

86 Errol P Mendes and Karima Karmali "Are There Hierarchies of Rights and Vulnerabilities Emerging Due to Deference, Context and Burden of Proof Standards?" (2003) 15 Nat'l J Const L 107, 118-119.

RJR-MacDonald Inc v Canada, above n 79, para 175 McLachlin J.

88 Ibid, para 212 Major J.

89

JTI MacDonald Corp v Canada, above n 76.

90 JTI MacDonald Corp v Canada, above n 76, para 7 McLachlin CJ for the Court. 
concern", and referred specifically to the protection of young persons from inducements to use tobacco products and subsequent dependence, and enhancing public awareness of health hazards. ${ }^{91}$

Six main issues were considered in JTI MacDonald, ranging from the effect of limits on scientific publications funded by the tobacco industry to the effects of these limits on advertising aimed at young people and the ban on sponsorship promotion. Each of these issues was considered individually, but the general conclusion reached was that the new scheme, enacted in the wake of the RJR-MacDonald decision, was "more restrained and nuanced" than the earlier legislation. ${ }^{92}$ The Tobacco Act, according to the Supreme Court, represented "a genuine attempt by Parliament to craft controls on advertising and promotion" that both met its own objectives and paid proper deference to the concerns that had led the court to making its earlier decision. ${ }^{93}$

Because this Act was better directed and its purpose provided clear justification for the restrictions placed the tobacco industry, the Court upheld these restrictions. This case recognised both that tobacco manufacturers have a right to commercial expression and that the legislature has a right to limit this expression in the interest of public health.

\section{E Current Outlook}

In an article immediately following the decision in JTI MacDonald, Penny Pepperell commented that: ${ }^{94}$

When international tobacco companies can argue, with some degree of success, that advertising

restrictions ... breach their constitutional right to freedom of expression, it makes one pause for thought

on the downside of codifying rights and freedoms.

It is easy to see why commentators may be concerned at the implications of cases such as RJRMacDonald and JTI MacDonald. Nonetheless it is difficult to argue why tobacco manufacturers, or other persons or organisations considered unpopular, should not have the same rights as all other persons and organisations, and why consumers of their products should not also have the same rights as all other consumers. Indeed, Martin Redish claims that the arguments relied upon to reduce protection for the expression of tobacco manufacturers "disintegrate" once "it is recognized that the regulation of tobacco advertising constitutes governmental suppression of an unpopular social message". ${ }^{95}$

\footnotetext{
91 Tobacco Act 1997, s 4.

92 JTI MacDonald Corp v Canada, above n 76, para 7 McLachlin CJ for the Court.

93 Ibid.

94 Penny Pepperell "Freedom of Expression for the Enemies of Public Health" (2007) 30 TCL 26 (1402).

95 Redish, above n 45, 581.
} 
The Canadian approach to tobacco advertising restriction is particularly interesting as a contrast to New Zealand's. In New Zealand, the District Court case of Director-General of Health $v$ Rothmans of Pall Mall found that applying the protection of freedom of expression available in the New Zealand Bill of Rights Act was irreconcilable with the Smoke-Free Environments Act. ${ }^{96}$ As a result, the restriction of freedom of expression contained within New Zealand's anti-smoking legislation was upheld. This issue has not been litigated since, although the potential remains for manufacturers to make a further appeal to the court on the grounds of protecting their right to freedom of expression. Should such action occur, Canada's experience in this area could be of particular interest.

What the Canadian cases illustrate is that construing a right to freedom of expression broadly can promote the value of the freedom but still permit limitations to be placed upon it. The Canadian Supreme Court clearly recognises that the commercial expression of tobacco manufacturers is entitled to the protection given to other forms of expression. It is also clear that, as the value of this speech may be less than that inherent in other forms of expression, this protection can be limited when it directly conflicts with specific and targeted objectives of the Canadian legislature.

\section{F Conclusion}

The Supreme Court of Canada has approached the issue of tobacco advertising in a way that both supports the legislature's attempts to promote public health and recognises that there is inherent value in allowing tobacco manufacturers the ability to express their side of the story. Before the most recent Canadian case was decided, commentators had suggested that the Supreme Court recognised in its decisions that while it is important to protect "vulnerable groups from the manipulation inherent with advertising", adults must also be considered "rational actors who can learn from experience and make their own decisions about the value of certain sources of information". ${ }^{97}$ In the end, regulation of advertising must recognise that consumers have a right to make their own decision about what products to purchase, from whom to purchase them, and at what cost.

The tobacco cases recognise the appropriateness of applying freedom of expression theory to commercial expression. Tobacco advertising is expression. It is expressive: it forwards views and provides information that, without it, would not be available to consumers. It can provide options for consumers to make brand choices, to choose lower tar or nicotine products that would be better for their future health. The courts recognise that, as much as smoking itself and the advertising of tobacco may not be popular, there may be some benefit in allowing consumers access to the information that advertising would provide.

96 Director-General of Health v Rothmans of Pall Mall (New Zealand) Ltd [1996] DCR 353 (DC).

97 McNaughton and Goodridge, above n 40, 536. 
Tobacco advertising, like all advertising, may contribute to the market-place of ideas, but in the end the Court's decision to allow tobacco advertisers to avail themselves of the protection of freedom of expression is rooted in the recognition that consumers, too, may benefit from some advertising. The choice to smoke may not be popular or wise, but it is in the end a legal choice, and one that all individuals are able to make in a free and democratic society. As such, limiting the information available about their options, in such a free and democratic society, should only be done when there is clear justification for such limitation. The refusal of the Supreme Court to permit limitations on tobacco advertising in RJR-Macdonald makes it clear that this protection is available, and will be applied to commercial expression unless limitations are sufficiently justified. The fact that these limitations were not upheld even in the face of a societal recognition of the unhealthy and even dangerous nature of smoking demonstrates the willingness of the Court to protect commercial expression and recognise its intrinsic value.

Respect for the values lying behind freedom of expression - for example, individual choice and autonomy - must advocate fewer, rather than more, restrictions on advertising. The tobacco cases illustrate that the Canadian Supreme Court is prepared to uphold these values, even on behalf of commercial expression, unless there is clear justification for their limitation. While the justification required may be less than what would be required in a non-commercial context, what a justifiable limit is will be decided on a case-by-case basis, ensuring the appropriateness of decisions in each case's individual circumstances.

\section{CONCLUSION: SO WHAT DOES THE COURT REALLY THINK?}

The Canadian Supreme Court's approach to commercial expression is an unusual one. This is true less because the Court recognises the right - a number of courts do this, including in New Zealand and the United States - and more because the right is recognised to be no different from the more general right to freedom of expression. There are no individualised tests for commercial expression, no lower threshold required for limitations to be considered against. In theory, at least, Canadian case law provides clear support for commercial expression protection.

Practice, however, is more contradictory. For while in theory the Court considers that commercial expression should be protected in the same way as non-commercial expression, the combined effect of Oakes and Edmonton Journal, and the individualised, case-by-case judgment approach they set out, ensures that in fact commercial expression is not given the same degree of protection as non-commercial expression. Case law clearly shows that while the Court considers that commercial expression does have intrinsic value, this value is not the same, or as great, as the value intrinsic to non-commercial expression.

As a result, the reasons given to limit the freedom need be less compelling for the Court to find them acceptable. In the end, it could appear that the Court has decided to give commercial expression protection that is theoretically on a par with the protection afforded to non-commercial 
expression, while simultaneously removing the possibility that this level of protection will ever, in reality, be applied.

This apparently contradictory approach may well be a logical compromise. In allowing freedom of commercial expression the full (rather than limited) protection of the Charter, the Supreme Court has ensured that potential remains for future commercial expression cases to be considered on a par with non-commercial expression cases. This potential remains even if no case has yet arisen where the level of protection given has reached a level comparable with non-commercial expression. It is not impossible that at some point a case will arise where the commercial nature of expression does not negate or even particularly limit the value of the expression in question, and as long as there is no rule requiring the Court to automatically apply a lower level of protection, this case will still receive the level of consideration, and the right the level of protection, to which it should be entitled. By refusing to follow the American example, the Canadian courts have ensured they have a flexible and wide-ranging approach that can be adapted to meet the individual requirements of individual cases.

The differences in approach between New Zealand and Canada's tobacco cases clearly result from the different levels of constitutional power residing in New Zealand's Bill of Rights Act and Canada's Charter of Rights and Freedoms. This difference does not make the Canadian approach to either freedom of commercial expression generally, or tobacco advertising restrictions specifically, irrelevant to New Zealand. Tobacco advertising restrictions may yet be further litigated in this country. Even if they are not, in a New Zealand context the Canadian approach to freedom of commercial expression is particularly interesting because it shows how to balance constitutional rights with the ability of the government to limit these rights. Should future cases involving freedom of commercial expression arise in New Zealand courts, Canada's flexible and yet rights-focused approach may provide valuable assistance in the development of a local response. 